\title{
Siting, disassaying and exfilling of the Mamão Dam in Ecuador/RN
}

\author{
Assoreamento, desassoreamento e desaterro do Açude Mamão em Equador/RN \\ Ubicación, desmontaje y explotación de la Presa Mamão en Ecuador/RN
}

Received: 14/12/2021 | Reviewed: 12/17/2021 | Accept: 12/22/2021| Published: 12/25/2021

\author{
Zenon Sabino de Oliveira \\ ORCID: https://orcid.org/0000-0001-5354-0236 \\ Universidade Federal de Campina Grande, Brazil \\ E-mail: zenonsabinogod@gmail.com \\ Isabel Lausanne Fontgalland \\ ORCID: https://orcid.org/0000-0002-0087-2840 \\ Universidade Federal de Campina Grande, Brazil \\ E-mail: isabelfontgalland@gmail.com
}

\begin{abstract}
Over four decades, there has been silting process of the riverbed that flows into the Mamão Dam, which supplies the water needs of the city of Ecuador-RN. This process has been taking place, caused largely by the receipt of mining tailings upstream of the reservoir. Thus, it became necessary the dredging consisting of removing the debris build-up and the bed debris and the riverbanks, offering a free flow to the waters that are intended for, and the excavation of the waste particles and accumulated sediment in the bed reservoir. For this, it was necessary; there were the necessary techniques for the conservation and proper maintenance so that did not occur obstruction of alluvial channel this spring. The work consisted of advice to the Municipality of the City of Ecuador, state of Rio Grande do Norte, where it made a technical feasibility study to recover the amount of previously existing water in the weir, were recovered to meet the population's consumption demand city and county. The study was conducted in 2013 and thus met the revitalization process and also the awareness of miners and miners, as the appropriate place for deposit of tailings stemmed these activities.
\end{abstract}

Keywords: Siltation; Dredging; Excavation; Dam Mamão.

\section{Resumo}

Ao longo de quatro décadas, vem ocorrendo o processo de assoreamento da calha do rio que deságua no Açude Mamão, que supre às necessidades hídricas da cidade de Equador-RN. Esse processo vem ocorrendo, ocasionado em larga escala pelo recebimento de rejeitos de mineradoras a montante do reservatório. Dessa forma, tornou-se necessário o desassoreamento consistindo em retirar o acúmulo de entulhos e detritos do leito e das margens do rio, oferecendo um fluxo livre às águas que se destinam ao açude, bem como o desaterro dos detritos, partículas e sedimentos acumulados no leito do reservatório. Para isso, tornou-se necessário, que houvesse as técnicas necessárias para a conservação e manutenção adequada para que não ocorresse a obstrução da calha aluvionar desse manancial. $O$ trabalho consistiu em assessoria à Prefeitura Municipal da cidade de Equador, estado do Rio Grande do Norte, onde se fez um estudo de viabilidade técnica para recuperação da quantidade de água anteriormente existente no açude, fosse recuperado para suprir a demanda de consumo da população da cidade e do município. O trabalho foi realizado no ano de 2013 e dessa forma, atendeu o processo de revitalização e também a conscientização das mineradoras e mineradores, quanto ao local adequado para depósito dos rejeitos provindos dessas atividades.

Palavras-chave: Assoreamento; Desassoreamento; Desaterro; Açude Mamão.

\section{Resumen}

A lo largo de cuatro décadas se ha producido un proceso de sedimentación del cauce del río que desemboca en la Presa Mamão, que abastece las necesidades hídricas de la ciudad de Ecuador-RN. Este proceso se ha venido produciendo, provocado en gran parte por la recepción de relaves mineros aguas arriba del embalse. Así, se hizo necesario el dragado consistente en remover la acumulación de escombros y los escombros del lecho y las riberas de los ríos, ofreciendo un flujo libre a las aguas destinadas, y la excavación de las partículas de desechos y sedimentos acumulados en el lecho del reservorio. Para esto, era necesario; Se contabilizaron las técnicas necesarias para la conservación y adecuado mantenimiento para que no ocurriera obstrucción de cauce aluvial este manantial. El trabajo consistió en asesorar a la Municipalidad de la Ciudad del Ecuador, estado de Rio Grande do Norte, donde se realizó un estudio de factibilidad técnica para recuperar la cantidad de agua previamente existente en la presa, se recuperaron para atender la demanda de consumo de la población de la ciudad y condado. El estudio se realizó en 2013 y así cumplió con el proceso de revitalización y también con la conciencia de los mineros y mineros, como el lugar adecuado para el depósito de relaves detuvo estas actividades.

Palabras clave: Sedimentación; Dragado; Excavación; Presa Mamão. 


\section{Introduction}

The low levels of precipitation and the irregularity of its regime in the Northeast region, notably in the Brazilian semiarid region, together with the hydrogeological context, contribute to the reduced values of water availability observed there. The semiarid region, in addition to low rainfall (less than $900 \mathrm{~mm}$ ), is characterized by high temperatures throughout the year, low temperature ranges (between $2^{\circ} \mathrm{C}$ and $3{ }^{\circ} \mathrm{C}$ ), strong insolation and high rates of evapotranspiration. The high rates of evapotranspiration normally exceed the irregular rainfall totals, configuring negative rates in the water balance (ANA, 2021). The dams are part of the Federal Government Policies to provides water available to the population I regard to specifics demands.

Ecuador-RN is the southernmost municipality in the state of Rio Grande do Norte (Figure 01), located in the Serido Potiguar/Brazil. With a population of 6,070 inhabitants, it is supplied by artesian wells from the Caiçara community and the main reservoir located in the Pau dos Ferros community, called Açude Mamao. When built in the early 1980s, it had a storage capacity of $1,300,000 \mathrm{~m}^{3}$. However, over the years, its reservoir has been depleted due to siltation and consequently the sedimentation of the weir bed, requiring the removal of material so that in its place, the water that previously occupied this space could be accumulated.

Figure 1: Location map of the city of Ecuador-RN.

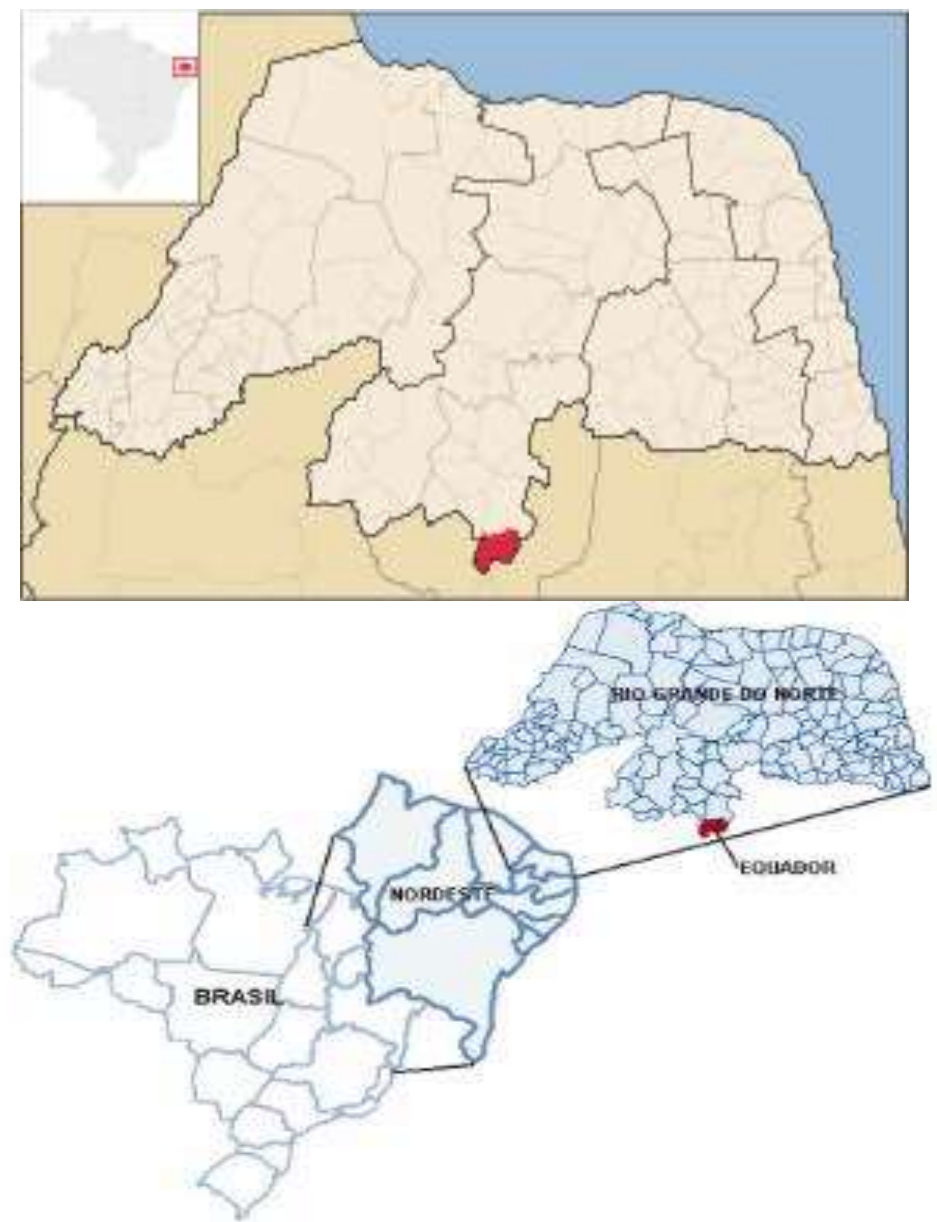

Source: https://PT. wikipedia.org/wiki/Ecuador_(Riograndedonorte). 
Knowing that the concept of silting can be defined as a process of accumulation of solid particles (sediments), in an aqueous or aerial medium, occurring when the force of the natural transport agent is overcome by the force of gravity or when the supersaturation of water or air allows the deposition of solid particles (Infantil Jr \& Fornasari Filho, 1998), this material brought along the natural course of the weir gutter, is composed of natural sediments of particles transported in suspension or rolling and material from mining tailings, composed of micas, quartz and feldspar, constituents of kaolin tailings.

According to OLIVEIRA, (1995), silting processes lead to the following problems: loss of reservoir volume; channel depth reduction; loss of efficiency of hydraulic works; flood production; deterioration of water quality; alteration and death of aquatic life.

\section{Methodology}

The worked area is located in the municipality of Ecuador-RN (Photo 01), in the Pau dos Ferros Community, inserted in the Mesoregion of Central Potiguar and Microregion of Seridó Oriental. The technical feasibility study on screen consisted of the recovery of the Mamão Reservoir, from the removal of sediments, sludges, rock fragments and minerals accumulated along its riverbed.

Figure 2: Aerial view of the Mamao Reservoir.

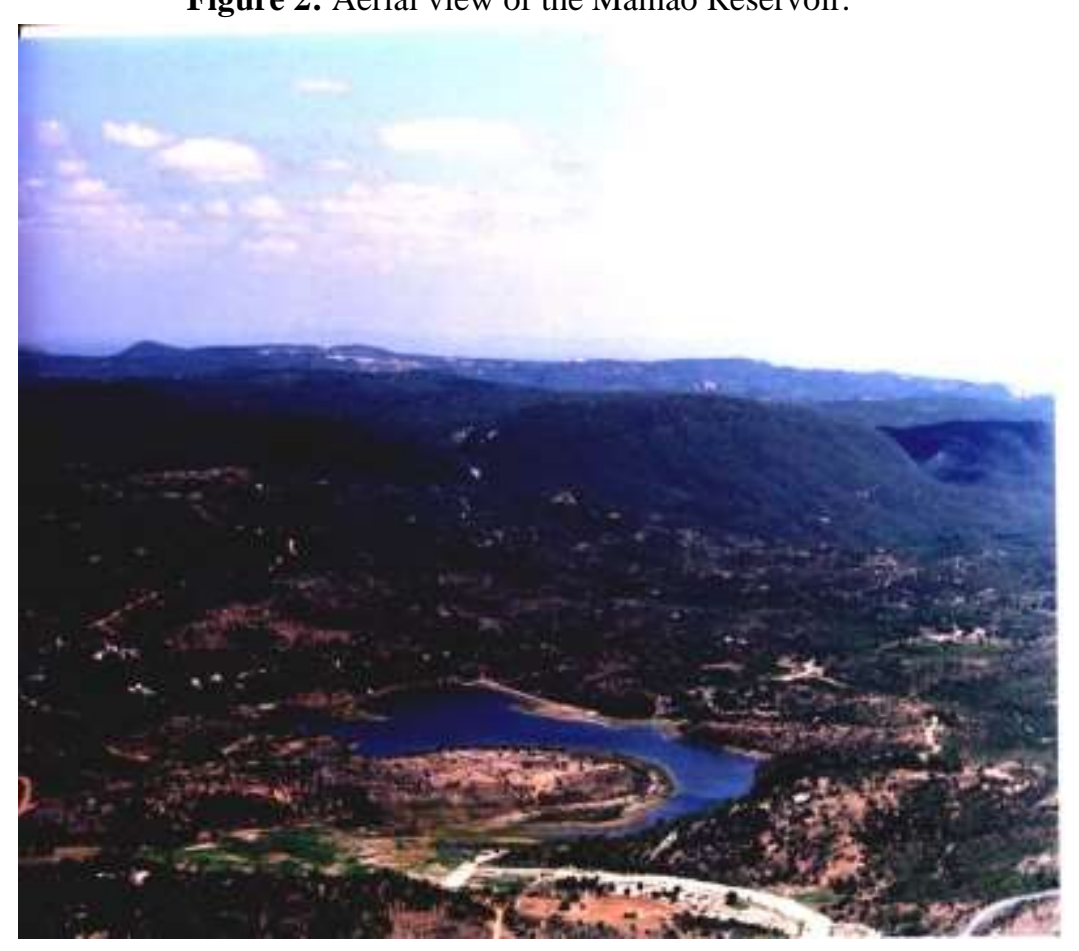

Source: Zenon Sabino de Oliveira (2005).

The methodology used consisted of conducting, previously, a topographic survey of the area to be studied for recovery. Then, an application was made to the Institute for Sustainable Development and Environment - IDEMA, where the environmental license was requested. It was also necessary the presence of a technical team from the State Water Resources Secretariat to verify and certify the project.

The objective was to provide an environmental license and the endorsement of the state's technical team, the work project was put into operation, which first consisted of cleaning the banks of the river and the weir with the help of a motorlevelling machine. In possession of a backhoe, the material consolidated in the weir gutter was excavated. After that, with a 
Research, Society and Development, v. 10, n. 17, e206101724742, 2021

(CC BY 4.0) | ISSN 2525-3409 | DOI: http://dx.doi.org/10.33448/rsd-v10i17.24742

filling shovel, the material was placed in bucket trucks, where it was deposited on the opposite side of the bucket, being consolidated with the machinery and trucks.

Figure 3: Backhoe and shovel filling machine removing sediment from the weir bed.

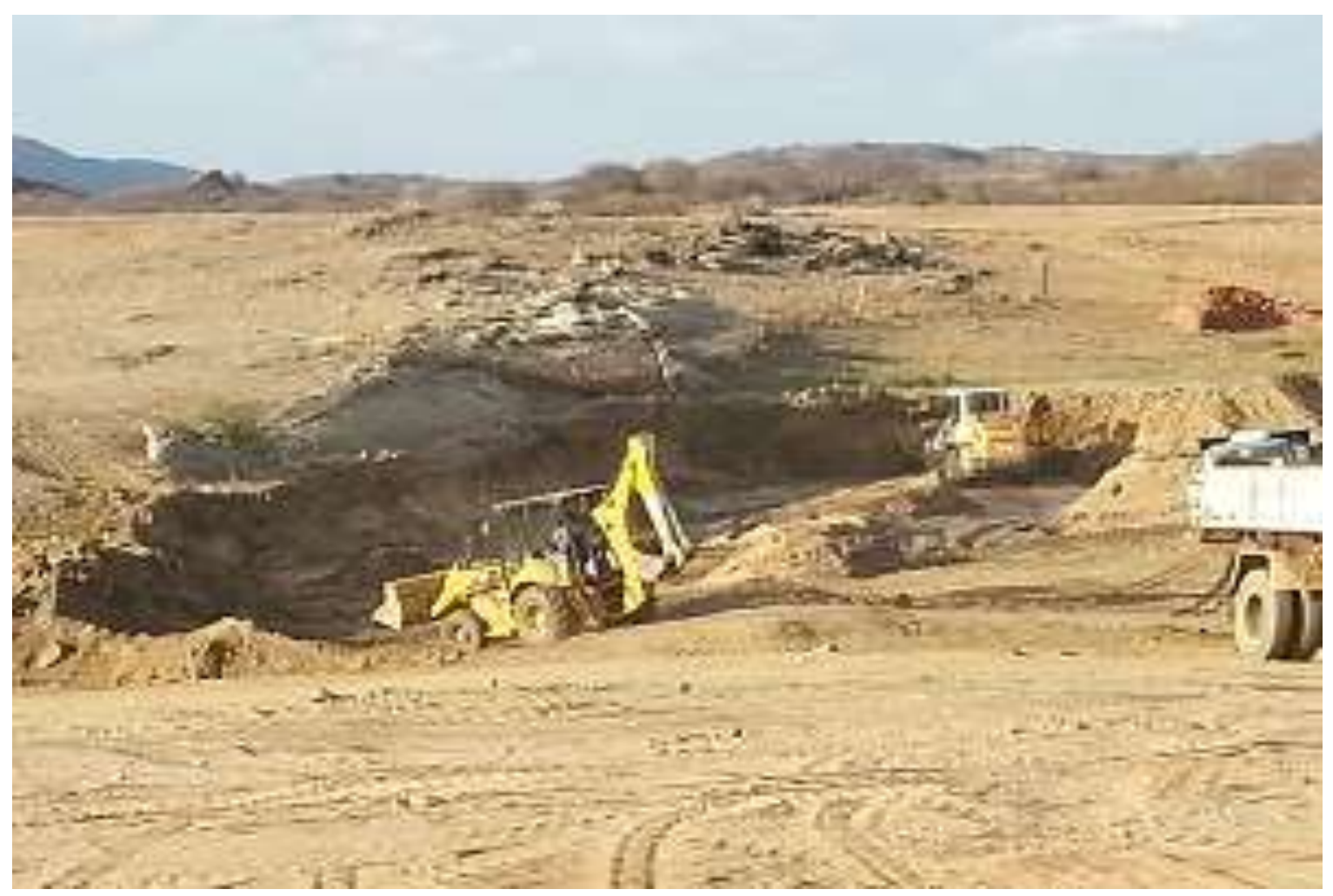

Source: Zenon Sabino de Oliveira (2013).

\section{Results and Discussion}

The 47 water reserves of Rio Grande do Norte are currently with 38\% of the total capacity occupied. This is what the most recent weekly report from the RN Water Management Institute (Igarn) points out. The reservoirs monitored by the institute all have capacities in excess of 5 million cubic meters of water and are responsible for supplying Potiguar cities. Two of the weirs are dry and another nine with a capacity below 10\% (see below). Altogether, RN's total surface water reserves currently accumulate $1,683,685,319 \mathrm{~m}^{3}$, corresponding to a total of 4,376,444,842 $\mathrm{m}^{3}$.

The Mamão Dam represents approximately $700,000 \mathrm{~m}^{2}$ of water storage, which would meet the needs of the population of that city. 
Figure 4: Bucket trucks transporting material and depositing it on the wall opposite the weir, strengthening it for a possible increase in its capacity.

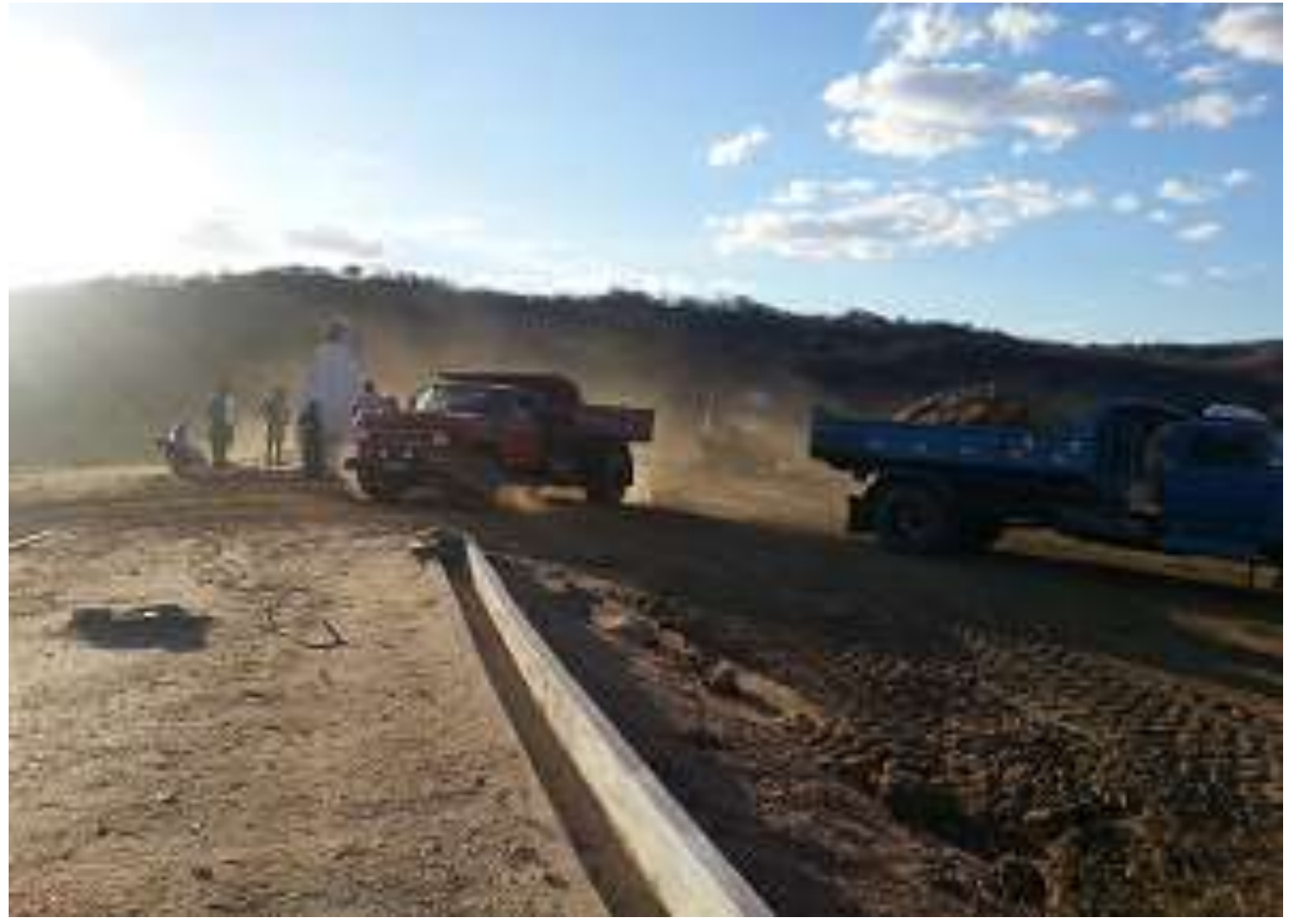

Source: Zenon Sabino de Oliveira (2013).

The budget for the execution of this activity was $\mathrm{R} \$ 150,000.00$ (one hundred and fifty thousand reais), the city's own resources. With regard to miners and miners, the city hall, through the Department of Works and Environment, carried out awareness-raising activities regarding the containment of tailings in pre-established deposits and preventing them from continuing to converge directly into the bed of the weir.

Another point that was discussed with the population was to prevent the removal of sand from the riverbanks, thus avoiding siltation and the consequent backfilling process from sediments, roots and other materials brought in as a result of these factors.

\section{Conclusion}

In light of the above, the work carried out presented results that proved that the effects of the dam on the physical chemistry of water and benthic were extremely important, since the losses in cubic meters were recovered, making up almost the entirety of the time of its construction in the 1980s, as well as the structure of the weir wall was ready to increase its capacity.

\section{Acknowledgments}

The acknowledgments are necessary to the Institute for Sustainable Development and Environment of the state of Rio Grande do Norte (IDEMA/RN), Secretariat of Water Resources and the Association of Municipalities of Seridó Oriental (AMSO). 
Research, Society and Development, v. 10, n. 17, e206101724742, 2021

(CC BY 4.0) | ISSN 2525-3409 | DOI: http://dx.doi.org/10.33448/rsd-v10i17.24742

\section{References}

Almeida, F. F. M. \& Ribeiro, A. C. O. (1998) A Terra em Transformação. In: Oliveira, A. M. S. \& Brito, S. N. A. (Eds.). Geologia de Engenharia. São Paulo: Associação Brasileira de Geologia de Engenharia (ABGE), in Cap. 1, p.7-13.

Augusto Filho, O (1995). Escorregamentos em encostas naturais e ocupadas: análise e controle. In: Bitar, O.Y. (1995) Curso de geologia aplicada ao meio ambiente. São Paulo: Associação Brasileira de Geologia de Engenharia (ABGE) e Instituto de Pesquisas Tecnológicas (IPT) in Cap. 3.4, p.77-100.

Agência nacional de energia elétrica; agência nacional de águas (2001) Introdução ao Gerenciamento de Recursos Hídricos. 2a ed. Arnaldo Augusto Setti; Jorge Enoch Furquim Werneck Lima; Adriana Goretti de Miranda Chaves; Isabella de Castro Pereira. Brasília, 328 p;

Audry, P.; Suassuna, J. A (1990) qualidade da Água na Irrigação do Trópico Semi-árido: um estudo de caso, In: Seminário Franco-Brasileiro de Pequena Irrigação, Pesquisa e Desenvolvimento, Anais do Encontro, Sudene e Embaixada da França, Recife, 11 a 13 de dezembro.

BRASIL (2021) https://www.ana.gov.br/sar

BRASIL (2021) Sistema de Acompanhamento de Reservatórios

Campos, J.N.B et al (2002). Sobre a eficiência de pequenos e grandes reservatórios. Disponível em: Acesso em 10 ago.

CERB (1996a). Barragem Apertado, Município Mucugê - Elaboração de Projeto Executivo da Barragem de Acumulação e suas Obras Complementares. Volume I - Relatório do Projeto. Tomo B.1 - Concepção e Estudos Básicos - Texto. 156p.

CERB (1996b). Barragem de França. Projeto Detalhado da Barragem e Estruturas Anexas XV Simpósio Brasileiro de Recursos Hídricos.

Gomes, R. M.; Filho, T. B. O. (2001) Proposta de manejo hídrico e de operação em reservatórios de estiagem no nordeste brasileiro visando o aumento das vazões regularizadas. In: Simpósio Brasileiro de Recursos Hídricos, 14.,2001, Aracaju. Anais... Aracaju: ABRH, 2001.1 CD.

Infanti Junior, N. \& Fornasari Filho, N. (1998) Processos de Dinâmica Superficial. In: Oliveira, A. M. S. \& Brito, S. N. A. (Eds.). Geologia de Engenharia. São Paulo: Associação Brasileira de Geologia de Engenharia (ABGE), Cap. 9, p.131-152.

Ministério do meio ambiente (2000) Agenda 21 brasileira - Bases para discussão. Brasília, pp.196

Ministério do meio ambiente (2002) Política Nacional de Recursos Hídricos. Brasília. P.43 a 57.

Molle, F. (1989) Perdas por evaporação e infiltração em pequenos açudes. Série Brasil. In SUDENE. Hidrologia. Recife, série.25, p. 11 A 70.

Silva, D. D.; Pruski, F. F. (2000) Gestão de Recursos Hídricos. Aspectos legais, econômicos, administrativos e sociais.Brasília. Ed. Secretaria de Recursos Hídricos, DF, Universidade Federal de Viçosa, ABRH, 2000. 659p.

Souza, F. (2001). Avaliação dos estudos hidroclimatológicos do Plano Estadual de Recursos Hidricos do Ceará: I - Evapotranspiração. Encontro das águasiica. Fortaleza. Http://www.iica.org.br/aguatrab/Francisco\%20de\%20 Souza/p4tb04.htm.

SRH Plano Diretor de Recursos Hídricos da Bacia do Médio e Baixo Paraguaçu. Volume VI - Documento síntese. 163p.

Oliveira, A. M. S. (1990) Depósitos Tecnogênicos Associados à Erosão Atual. In: Congresso brasileiro de geologia de engenharia, 6, 1990, São Paulo. Anais... São Paulo: ABGE/ABMS, P.411-416. 